\title{
THROUGHFALL IN DIFFERENT FOREST STANDS OF IPERÓ, SÃO PAULO
}

\author{
Esthevan Augusto Goes Gasparoto ${ }^{1}$, Kelly Cristina Tonello ${ }^{1 *}$, Emily Tsiemi Shinzato ${ }^{1}$, Roberta de Oliveira Averna Valente ${ }^{1}$ \\ *Autor para correspondência: kellytonello@ufscar.br
}

\begin{abstract}
In forestry, throughfall (Pi) is that fraction of rainfall that runs directly through the tree canopy and reaches the ground. It is characterized as the main source of water supply in a watershed. This study aimed to analyze the dynamics of throughfall in three types of forest stands, namely Eucalyptus cloeziana, Pinus sp. and seasonal semideciduous forest (FES), all located in Ipanema National Forest, in the municipality of Iperó-SP. In each stand, a $300 \mathrm{~m}^{2}$ plot was established in which ten rain gauges were installed for monitoring throughfall, and three rain gauges were installed in an open area adjacent to the stand for measuring gross precipitation (P). At the end of 25 observations, it was observed that, relative to P values, Pi values were $76.2 \%$ in semideciduous forest (FES), $85.1 \%$ in E.cloeziana forest and $84.0 \%$ in Pinus sp forest. In addition, comparing these stands, a larger leaf canopy coverage and consequently greater capability for water retention was noted in the semideciduous forest. However, no statistical differences were observed $(P<0.05)$ between the stands of interest regarding throughfall.
\end{abstract}

Keywords: net precipitation, interception, forest hydrology

\section{PRECIPITAÇÃO INTERNA EM DIFERENTES POVOAMENTOS FLORESTAIS EM IPERÓ, SP}

RESUMO: A precipitação interna (Pi) numa floresta consiste na fração da chuva que atravessa o dossel e atinge a superfície do solo. Essa caracteriza-se como a principal fonte de abastecimento de água em uma bacia hidrográfica. No presente estudo, analisouse a dinâmica da Pi em três povoamentos florestais (Eucalyptus cloeziana, Pinus sp. e Floresta Estacional Semidecidual (FES)), localizados na Floresta Nacional de Ipanema, no município de Iperó-SP. Para tanto, delimitou-se em cada povoamento uma parcela com área de $300 \mathrm{~m}^{2}$, contendo cada uma dez pluviômetros para monitoramento de Pi e três pluviômetros dispostos em área aberta, anexa ao povoamento, a fim de se obter a precipitação em aberto (P). Ao final de 25 observações, verificaram-se que os valores de Pi em relação à $\mathrm{P}$ foram $76,2 \%$, na FES, $85,1 \%$ na parcela de E. cloeziana e $84,0 \%$ na de Pinus sp. Além disso, para cada um desses povoamentos, respectivamente, observou-se uma maior cobertura foliar e capacidade de retenção de água no dossel na FES. Apesar disso, não foram observadas diferenças estatísticas $(\mathrm{P}<0,05)$ de $\mathrm{Pi}$ entre os diferentes povoamento estudados.

Palavras-chave: precipitação efetiva, interceptação, hidrologia florestal

\section{INTRODUCTION}

In hydrology, precipitation is defined as any form of water from the atmosphere in any physical state that reaches the earth's surface, with rainfall (rain precipitation) being the most important type of precipitation for hydrology and its related branches (BERTONI; TUCCI, 2001). The portion of rainfall that reaches the forest floor is known as net precipitation and may be subdivided into the two components, throughfall (Pi) and stemflow (Et) (KLASSEN et al., 1996).

Throughfall is rainfall that is not intercepted by the crown canopy and includes both the water drops that pass directly through canopy openings and the water drops that drip from the crown canopy (OLIVEIRA JÚNIOR; DIAS, 2005). Compared with water that runs down the tree stems, throughfall is known to be the largest contributor to water replacement in watersheds and to maintenance of hydrologic dynamics in forests (ARCOVA et al., 2003; OLIVEIRA JÚNIOR; DIAS, 2005).

1 Universidade Federal de São Carlos - Sorocaba, São Paulo, Brasil
According to studies performed in tropical forests, throughfall accounts for about $75 \%$ to $96 \%$ of gross rain precipitation (P) (OLIVEIRA et al., 2008). In the case of nonnative pine and eucalyptus forests, throughfall rates are usually higher in hardwood stands than in softwood stands (LIMA, 1976).

Scheer (2009) studied the contribution of rainfall to nutrient flow in rain forests and noted that, by dragging the nutrients suspended in the atmosphere and subsequently washing them away from the surface of the leaves, rain precipitation plays an important part in returning such nutrients to the forest floor. The author observed that $65 \%$, $15 \%$ and $5 \%$ of the flows of, respectively, potassium $(\mathrm{K})$, magnesium $(\mathrm{Mg})$ and calcium $(\mathrm{Ca})$ to the forest floor was effected by throughfall.

From a scientific standpoint, it is understood that, whether natural or planted, forests have specific requirements of nutrients, light and water, the latter being directly influenced by human actions such as land use and occupation, and that in turn may have positive or negative impacts on soil water recharge and surface runoff.

Cerne, Lavras, v. 20, n. 2, p. 303-310, abr./jun. 2014 
Considering the pressing need to secure soil water availability, and challenged by the effects that forest management in different forest stands may have on throughfall, it would be desirable to monitor water availability in different environments in order to understand its patterns of behavior.

The objective of this study was to compare different forest stands (semideciduous forest, Eucalyptus cloeziana and Pinus sp.) as to their influence on throughfall distribution in Ipanema National Forest, Iperó - SP, in an attempt to contribute information to help with decisionmaking and with the hydrologic management of Ipanema Forest.

\section{MATERIAL AND METHODS}

This study was conducted in Ipanema National Forest (FLONA Ipanema), which is located in southeastern São Paulo state, between geographic coordinates $23^{\circ}$ $25^{\prime}$ and $23^{\circ} 27^{\prime}$ south latitude, and $47^{\circ} 35^{\prime}$ and $47^{\circ}$ 40 ' west longitude, with altitude ranging from 550 $\mathrm{m}$ to $968 \mathrm{~m}$ (REGALADO, 1999). The local climate, according to Köppen classification, is Cfa type, a humid subtropical climate with well-defined rainy and dry seasons (ALBUQUERQUE, 1999). Average rainfall in the Ipanema Forest region is about $1,400 \mathrm{~mm}$ per year, with minimum records of $800 \mathrm{~mm}$ and maximum records of 2,200 $\mathrm{mm}$ in the period between 1973 and 2003 (SOUZA; MARTOS, 2008). According to RADAMBRASIL (1984), the vegetation in Ipanema Forest is characterized as typical of a transition area (ecological stress) between different ecosystems, and includes semideciduous forest, cerrado and dense rain forest as the main plant formations, along with areas of nonnative Eucalyptus sp. and Pinus sp. forests, all of which enable the study to take place.

For throughfall (Pi) monitoring, plots $15 \times 20 \mathrm{~m}$ in size were established in the forest fragments, namely a semideciduous forest (FES) undergoing 35 years of natural regeneration, a 15-year-old stand of Eucalyptus cloeziana and a 12-year-old stand of Pinus sp. (Figures 1B, 1C and $1 \mathrm{D}$ respectively). The plots were about 1.7 kilometers apart from each other (Figure 1A).

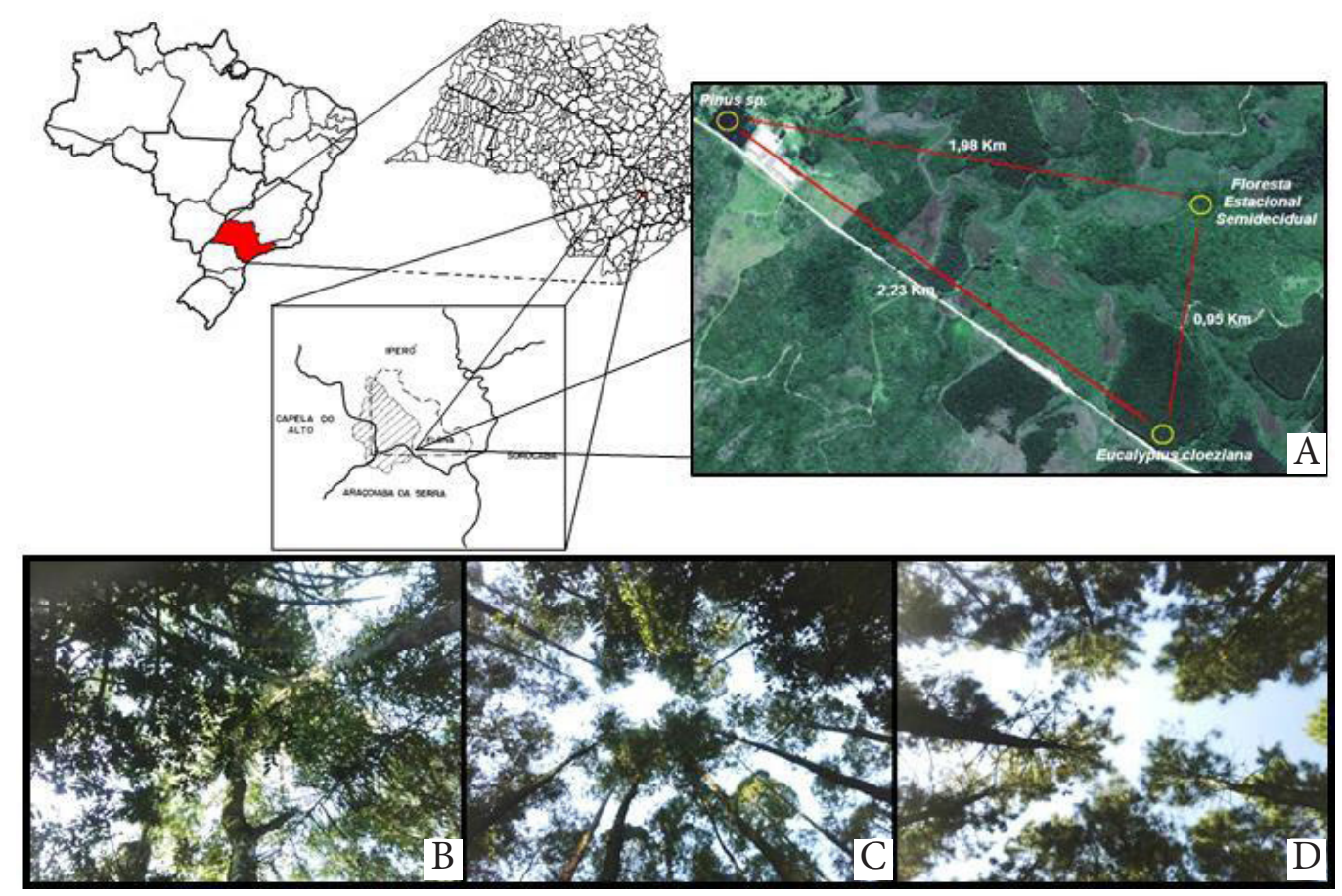

Figure 1 - Location of Ipanema National Forest and distribution of sampling units (1a), crown canopy over the rain gauges, in semideciduous forest (1b), in the Eucalyptus cloeziana stand (1c) and in the Pinus sp. stand (1d). Ipanema National Forest, Iperó-SP, June/2009 to July/2010.

Figura 1 - Localização da FLONA Ipanema e distribuição das unidades amostrais (1a), cobertura do dossel sobre os pluviômetros, na FES (1b), Eucalyptus cloeziana (1c) e Pinus sp. (1d). Floresta Nacional de Ipanema, Iperó-SP, Junho/2009 a Julho/2010.

Cerne, Lavras, v. 20, n. 2, p. 303-310, abr./jun. 2014 
For throughfall quantification, ten rain gauges were randomly installed in each plot according to the methodology proposed by Thomaz (2005). To make the rain gauges, water bottles with a storage capacity of 5 to 10 liters were used. For the collecting funnels, 2-liter plastic bottles were cut in two and the neck portion was upturned in order to channel the water flow into the bottle. The collection area of each gauge was monitored throughout the study to prevent miscalculations resulting from deformations. To transform the water volume stored in each gauge into measures of water depth $(\mathrm{mm})$, the following equation was used:

$$
\mathrm{Pi}=\mathrm{V} / \mathrm{A}
$$

where Pi is throughfall ( $\mathrm{mm}), \mathrm{V}$ is volume of rainwater stored in each gauge (L) and $\mathrm{A}$ is funnel collection area of each gauge $\left(\mathrm{m}^{2}\right)$.

For quantification of gross precipitation $(\mathrm{P})$ in each forest type, a rain gauge was installed in an open area adjacent to the respective plot, away by about $600 \mathrm{~m}$ from the plot. To convert $\mathrm{P}$ into $\mathrm{mm}$, the same method used for $\mathrm{Pi}$ was used, see equation 1.

All readings of $P$ and Pi were started at 8 a.m. the morning after an occurrence of rain, with volume being quantified by means of a graduated cylinder.

For determination of canopy coverage $(\mathrm{CF} \%)$ in each forest type, five digital images were obtained using a DSC-H5 Sony digital camera mounted on a tripod $50 \mathrm{~cm}$ above the ground (same height as the collecting funnel), taken from near the collectors. All images were acquired in automatic mode (MONTE et al., 2007) at a minimum focal length of $6 \mathrm{~mm}$, which is equivalent to a $36 \mathrm{~mm}$ focal length in $35 \mathrm{~mm}$ cameras.

The images were subsequently trimmed in such way that only $25 \%$ of the total area was used, referring to the center portion. They were then processed using the image processing software IDRISI Andes and reclassified to grayscale. A histogram was drawn to visually quantify the percentage of pixels representing canopy coverage and the percentage of pixels representing canopy openings (absence of leaves, branches or stems) through which water can run freely without being intercepted by the crown canopy. The mean percentage of all five images was then taken to represent the canopy coverage projected onto the forest floor. Crown canopy overlap (SC) was calculated by dividing the product of mean canopy area and number of trees in the plot by total plot area. The result provides the canopy area in $\mathrm{m}^{2}$ that is projected onto $1 \mathrm{~m}^{2}$ of forest floor.
To identify differences in the partitioning of rainfall among the stands of interest, throughfall data $(\mathrm{Pi})$ were subjected to analysis of variance and Tukey test to compare the means $(\mathrm{P}<0.05)$ using software Minitab 14.0. A completely randomized design was used in which each forest type was considered a treatment, with 25 observations of rain occurrence in each forest type between November 2009 and May 2010.

Results of gross precipitation (P) and throughfall (Pi) for each stand were subjected to linear regression analysis and, by means of the linear regression coefficient, the capability of rainfall retention by the crown canopy was obtained, according to Moura et al. (2009).

\section{RESULTS AND DISCUSSION}

Throughout the study period, aggregate rain precipitation outside the stands $(\mathrm{P})$ averaged $519.9 \mathrm{~mm}$, and the largest sum was observed in the gauge near semideciduous forest (FES). Although the plots were close to one another, the total amplitude of $\mathrm{P}$ was 40.8 $\mathrm{mm}$, between highest (FES) and lowest incidence (Pinus sp.). That shows the importance of installing gauges in open areas adjacent to each stand for measuring $\mathrm{P}$, since throughfall (Pi) quantification is calculated as a function of $\mathrm{P}(\%)$, that way eliminating the effect of spatial variability in rainfall among forest formations.

That said, in some occurrences of rain it was observed that average throughfall $(\mathrm{Pi})$ was greater than P. While impossible in theory, this was also observed by other researchers (KELLMAN; ROULET, 1990; MOURA et al., 2009). A justification could be that the intertwining of tree branches may cause water to run down specific routes, generating both drip points and shielded areas, which respectively increase rain flow into some gauges and reduce rain flow into other gauges. Additionally, such variability could be due to variations in forest structure and in intervals between rain occurrences, irregular topography, geometric edge, tree spacing and tree size (MOURA et al., 2009; NEAL et al., 1991).

Throughfall monitoring over the study period revealed aggregate throughfall of $411.8 \mathrm{~mm}$ in semideciduous forest (FES), $443.0 \mathrm{~mm}$ in the Eucalyptus cloeziana stand and $419.5 \mathrm{~mm}$ in the Pinus sp. stand, which correspond respectively to $76.2 \%, 85.1 \%$ and $84.0 \%$ of total P (Table 1).

Similarly to the above result in semideciduous forest, Oliveira et al. (2008) monitored throughfall in a

Cerne, Lavras, v. 20, n. 2, p. 303-310, abr./jun. 2014 
native forest fragment located in Caxiuanã - PA and found that $76.8 \%$ of total precipitation corresponded to Pi. Alves et al. (2007) and also Oliveira Junior and Dias (2005) studied throughfall behavior in fragments of secondary
Atlantic forest, both in Viçosa - MG, and found higher values than the findings in this study, around $80 \%$ and $80.9 \%$ of Pi respectively. Ferreira et al. (2005) compared throughfall in a fragment of upland forest subjected to

Table 1 - Mean gross rainfall (P), throughfall (Pi) and percentage ratio (Pi/P) in stands of semideciduous forest (FES), Eucalyptus cloeziana and Pinus sp. - Ipanema National Forest, Iperó-SP, 2009-2010.

Tabela 1- Valores médios da precipitação pluvial em aberto $(\mathrm{P})$, da precipitação pluvial interna (Pi) e relação percentual (Pi/P) nos povoamentos de Floresta Estacional Semidecidual (FES), Eucalyptus cloeziana e Pinus sp. Floresta Nacional de Ipanema, Iperó-SP, 2009-2010.

\begin{tabular}{|c|c|c|c|c|c|c|c|c|c|c|}
\hline \multirow[b]{2}{*}{ Sampling* } & \multirow[b]{2}{*}{ Date } & \multicolumn{3}{|c|}{ FES } & \multicolumn{3}{|c|}{ E. cloeziana } & \multicolumn{3}{|c|}{ Pinus sp. } \\
\hline & & $\begin{array}{c}\mathrm{Pi} \\
(\mathrm{mm})\end{array}$ & $\begin{array}{c}\mathrm{P} \\
(\mathrm{mm})\end{array}$ & $\begin{array}{l}\mathrm{Pi} / \mathrm{P} \\
(\%)\end{array}$ & $\begin{array}{c}\mathrm{Pi} \\
(\mathrm{mm})\end{array}$ & $\begin{array}{c}\mathrm{P} \\
(\mathrm{mm})\end{array}$ & $\begin{array}{l}\mathrm{Pi} / \mathrm{P} \\
(\%)\end{array}$ & $\begin{array}{c}\mathrm{Pi} \\
(\mathrm{mm})\end{array}$ & $\begin{array}{c}\mathrm{P} \\
(\mathrm{mm})\end{array}$ & $\begin{array}{l}\mathrm{Pi} / \mathrm{P} \\
(\%)\end{array}$ \\
\hline 1 & $\begin{array}{c}\text { 09/11/20 } \\
\text { http://dx.doi. }\end{array}$ & 12.2 & 13.6 & 89.7 & 14.2 & 18.2 & 78.2 & 10.3 & 11.2 & 92.5 \\
\hline 2 & $16 / 11 / 2009$ & 33.9 & 19.6 & 173.1 & 40.7 & 51.6 & 78.9 & 33.2 & 37.2 & 89.3 \\
\hline 3 & $22 / 11 / 2009$ & 50.3 & 71.3 & 70.6 & 46.5 & 66.6 & 69.8 & 33.2 & 43.7 & 75.9 \\
\hline 4 & $28 / 112009$ & 16.2 & 16.6 & 97.9 & 18.9 & 21.8 & 86.8 & 18.9 & 19.2 & 98.7 \\
\hline 5 & $30 / 11 / 2009$ & 21.3 & 33.1 & 64.4 & 25.5 & 31.9 & 79.9 & 24.9 & 30.9 & 80.5 \\
\hline 6 & $21 / 1 / 2010$ & 31.1 & 40.7 & 76.3 & 36.4 & 49.0 & 74.4 & 52.5 & 57.6 & 91.0 \\
\hline 7 & $22 / 1 / 2010$ & 8.1 & 12.9 & 62.5 & 10.3 & 10.9 & 94.6 & 8.1 & 9.6 & 84.4 \\
\hline 8 & $24 / 1 / 2010$ & 20.3 & 20.1 & 101.1 & 12.2 & 18.9 & 64.5 & 9.2 & 31.2 & 29.5 \\
\hline 9 & $26 / 1 / 2010$ & 9.7 & 23.0 & 41.9 & 2.9 & 2.9 & 102.8 & 24.9 & 30.6 & 81.5 \\
\hline 10 & $29 / 1 / 2010$ & 26.5 & 36.8 & 72.1 & 30.5 & 37.1 & 82.2 & 35.9 & 33.4 & 107.5 \\
\hline 11 & $30 / 1 / 2010$ & 1.4 & 3.4 & 41.8 & 2.9 & 2.9 & 98.7 & 1.6 & 3.2 & 48.8 \\
\hline 12 & $31 / 1 / 2010$ & 7.5 & 11.0 & 67.8 & 9.2 & 12.5 & 73.8 & 8.7 & 9.6 & 90.2 \\
\hline 13 & $01 / 2 / 2010$ & 23.3 & 27.9 & 83.5 & 33.9 & 21.7 & 156.3 & 24.8 & 26.4 & 93.9 \\
\hline 14 & $10 / 2 / 2010$ & 35.8 & 45.2 & 79.1 & 45.1 & 47.9 & 93.9 & 36.3 & 37.2 & 97.7 \\
\hline 15 & $11 / 2 / 2010$ & 0.5 & 1.2 & 45.3 & 0.6 & 0.6 & 94.6 & 0.7 & 0.8 & 84.5 \\
\hline 16 & $17 / 2 / 2010$ & 9.0 & 11.7 & 77.1 & 9.3 & 11.6 & 80.1 & 9.7 & 10.8 & 89.5 \\
\hline 17 & $18 / 2 / 2010$ & 0.7 & 2.2 & 29.8 & 1.5 & 3.6 & 40.9 & 0.8 & 1.7 & 50.0 \\
\hline 18 & $25 / 2 / 2010$ & 10.4 & 11.6 & 89.8 & 10.9 & 12.4 & 88.4 & 7.1 & 10.1 & 70.4 \\
\hline 19 & $01 / 3 / 2010$ & 26.6 & 28.1 & 94.4 & 24.9 & 33.0 & 75.7 & 24.7 & 27.0 & 91.4 \\
\hline 20 & $07 / 3 / 2010$ & 5.0 & 36.0 & 14.0 & 3.9 & 3.6 & 107.6 & 3.9 & 5.6 & 70.4 \\
\hline 21 & $09 / 3 / 2010$ & 0.8 & 2.9 & 27.0 & 1.5 & 2.2 & 73.4 & 1.4 & 2.4 & 56.2 \\
\hline 22 & $14 / 3 / 2010$ & 23.0 & 26.9 & 85.4 & 28.1 & 23.3 & 121.2 & 21.3 & 21.6 & 98.4 \\
\hline 23 & $21 / 3 / 2010$ & 8.2 & 13.3 & 61.9 & 9.5 & 10.0 & 96.1 & 6.1 & 8.4 & 73.1 \\
\hline 24 & $23 / 3 / 2010$ & 4.2 & 5.9 & 71.7 & 6.3 & 10.8 & 59.8 & 4.5 & 6.4 & 69.9 \\
\hline 25 & $08 / 5 / 2010$ & 25.8 & 25.2 & 102.5 & 16.9 & 15.5 & 111.2 & 16.8 & 23.5 & 71.6 \\
\hline
\end{tabular}

${ }^{\star}$ Each sampling unit corresponded to the average of 10 observations.

Cerne, Lavras, v. 20, n. 2, p. 303-310, abr./jun. 2014 
selective logging with throughfall in an untouched forest in Central Amazonia and found values ranging from $87 \%$ to $93 \%$ and $74.2 \%$ to $87.1 \%$ respectively, concluding that there was no statistical difference.

Regarding nonnative forests, Lima (1976) studied throughfall behavior in stands of Eucalyptus saligna and Pinus caribaea located in Piracicaba - SP, and found that it accounted respectively for $83.6 \%$ and $90.4 \%$ of $\mathrm{P}$. These results are similar to the findings in this study for Eucalyptus sp. and higher than the findings for Pinus sp. The aforementioned study, however, dealt with 6-year-old stands whereas this study dealt with 15-year-old Eucalyptus cloeziana and 12-year-old Pinus sp. It should be noted that factors such as age, management system, density, species and abiotic events (wind, rainfall intensity, among others) may influence the amount of throughfall in homogeneous planted forests.

The statistical analysis revealed no significant differences $(\mathrm{P}<0.05)$ between the three forest stands regarding total amount of throughfall $(\mathrm{mm})$ and relative amount of throughfall (\%), indicating that the amount of rainwater reaching the forest floor by throughfall is the same, regardless of forest type and considering the particularities of the stands in Ipanema National Forest. However, it should be noted that different results might have been found if the relevant stands were the same age and had the same tree density.

Imaging results revealed greater leaf density in the plot with semideciduous forest, with $81.8 \%$ of leaf canopy coverage, against a density of $74.7 \%$ in the Pinus sp. plot. Such values may be justified by the number of trees present, 54 trees in the first plot against a mere 29 trees in the second plot, in addition to crown canopy overlap, as shown in Table 2. However, the analysis of variance (ANOVA) revealed no significant differences between the three stands regarding canopy coverage.

Based on Table 1 observations, a scatter plot was constructed for each forest stand along with linear regression models (Figures 2a, 2b and 2c) between Pi and P. The highest coefficients of determination were found for Eucalyptus cloeziana and Pinus sp., reflecting greater homogeneity in both growth and development.

The linear regression coefficient revealed that semideciduous forest (FES) had greater capability of rainfall retention by the crown canopy $(3.9 \mathrm{~mm})$. This information corroborates the value of leaf coverage provided in Table 2 in that the greater the water retention capability by the canopy is, the lower the Pi value.
Table 2 - Results summary obtained in the study. AP = plot area; $N=$ number of trees in the plot; mean $A C=$ mean crown canopy area; $A C \times N$ = product of mean crown canopy area and number of trees; $S C=$ crown canopy overlap; $C F=$ leaf canopy coverage; $P i=$ throughfall.

Tabela 2 - Resumo dos resultados obtidos no estudo. AP = área da parcela; $\mathrm{N}$ = número de indivíduos arbóreos na parcela; $\mathrm{AC}=$ média da área das copas; $\mathrm{AC} \mathrm{x} \mathrm{NI}=$ produto entre a média da área das copas e o número de indivíduos; $\mathrm{SC}=$ sobreposição das copas; $\mathrm{CF}=$ Cobertura foliar; $\mathrm{Pi}$ = precipitação interna.

\begin{tabular}{lccccccc}
\hline Forest Stand & $\begin{array}{c}\mathrm{AP} \\
\left(\mathrm{m}^{2}\right)\end{array}$ & $\begin{array}{c}\mathrm{N} \\
(\mathrm{un} .)\end{array}$ & $\begin{array}{c}\mathrm{AC} \\
\left(\mathrm{m}^{2}\right)\end{array}$ & $\begin{array}{c}\mathrm{AC} \times \mathrm{N} \\
\left(\mathrm{m}^{2}\right)\end{array}$ & $\begin{array}{c}\mathrm{SC} \\
\left(\mathrm{m}^{2}\right)\end{array}$ & $\begin{array}{c}\mathrm{CF} \\
(\%)\end{array}$ & $\begin{array}{c}\mathrm{Pi} \\
(\%)\end{array}$ \\
\hline FES & 300 & 54 & 18.0 & 522.9 & 1.7 & 81.8 & 76.2 \\
E. cloeziana & 300 & 50 & 9.8 & 489.3 & 1.6 & 79.3 & 85.1 \\
Pinus sp. & 300 & 29 & 11.8 & 342.2 & 1.1 & 74.7 & 84.0 \\
\hline
\end{tabular}
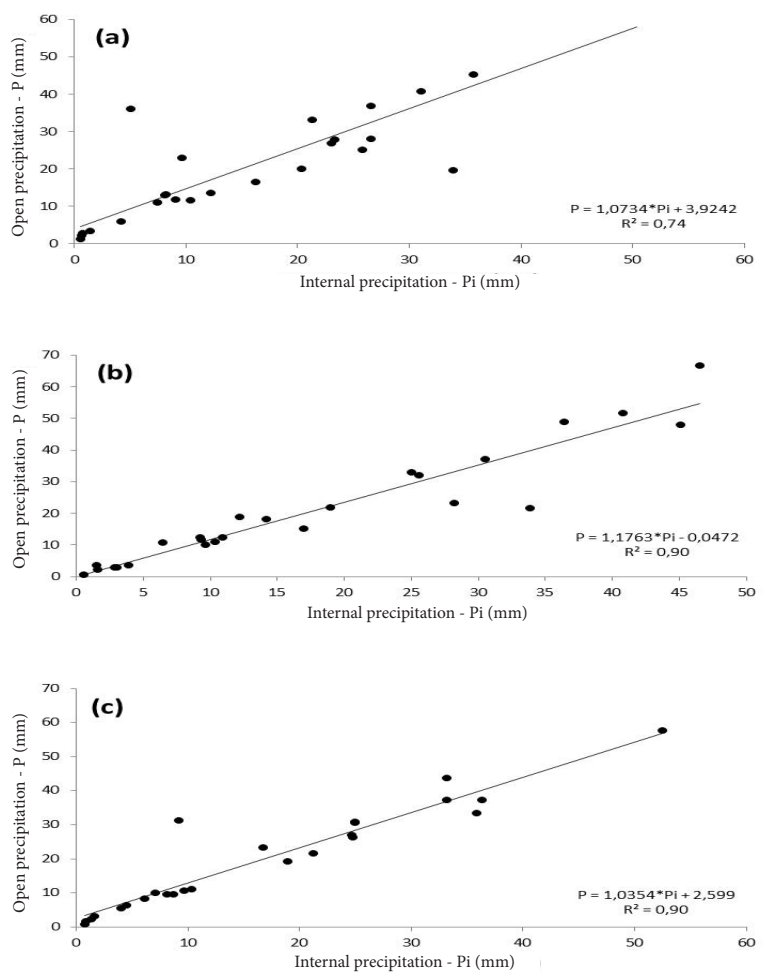

Figure 2 - Scatter plot of throughfall (Pi) as a function of gross precipitation $(P)$ in stands of (a) semideciduous forest (FES), (b) Eucalyptus cloeziana and (c) Pinus sp. - Ipanema National Forest, Iperó-SP, 2009-2010.

Figura 2 - Dispersão entre a precipitação pluvial interna (Pi), em função da precipitação pluvial em aberto (P), para os povoamentos de: (a) Floresta Estacional Semidecidual, (b) Eucalyptus cloeziana e (c) Pinus sp.. Floresta Nacional de Ipanema, Iperó-SP, 2009-2010.

Cerne, Lavras, v. 20, n. 2, p. 303-310, abr./jun. 2014 
Comparatively, Moura et al. (2009) found a higher value $(4.9 \mathrm{~mm})$ in a fragment of Atlantic forest. Arcova et al. (2003) and also Oliveira Junior and Dias (2005) reported lower mean values of total precipitation capable of promoting throughfall, respectively 0.62 and $1.28 \mathrm{~mm}$. Rodrigues (2009) studied throughfall in a stand of Hevea brasiliensis and obtained $0.29 \mathrm{~mm}$. As for Pinus sp., a result close to that in this study $(2.04 \mathrm{~mm})$ was found by Calux and Thomaz (2012) in a study with Pinus elliottii forest.

\section{CONCLUSION} drawn:

Based on results, the following conclusions were

- Throughfall (Pi) accounted for $76.2 \%, 85.1 \%$ and $84.0 \%$ of gross precipitation $(\mathrm{P})$, respectively in the stands of semideciduous forest, Eucalyptus cloeziana and Pinus sp.

- No statistical differences were found at the $5 \%$ probability level between the three stands of interest regarding the values of throughfall $(\mathrm{Pi})$.

- Results of water retention capability by the crown canopy were $3.92,0.04$ and $2.60 \mathrm{~mm}$, respectively in the stands of semideciduous forest, Eucalyptus cloeziana and Pinus sp.

\section{AGRADECIMENTOS}

Aos técnicos Cícero Branco e Ivonir Piotrowski pelo auxílio nos trabalhos de campo. À equipe da Floresta Nacional de Ipanema pelo apoio. Ao CNPq pela concessão da Bolsa de Iniciação Cientifica.

\section{REFERENCES}

\section{ALBUQUERQUE, G. B. Floresta Nacional de Ipanema: caracterização da vegetação em dois trechos distintos do Morro de Araçoiaba, Iperó, SP. 1999. 186 p. Dissertação (Mestrado em Ciências Florestais) - Escola Superior de Agricultura "Luiz de Queiroz”, Piracicaba, 1999.}

ALVES, R. F.; DIAS, H. C. T.; OLIVEIRA JUNIOR, J. C.; GARCIA, F. N. M. Avaliação da precipitação efetiva de um fragmento de Mata Atlântica em diferentes estágios de regeneração no município de Viçosa, MG. Ambi-Água, Taubaté, v. 2, n. 1, p. 83-93, 2007.

Cerne, Lavras, v. 20, n. 2, p. 303-310, abr./jun. 2014
ARCOVA, F. C. S.; CICCO, V.; ROCHA, P. A. B. Precipitação efetiva e interceptação das chuvas por floresta de mata atlântica em uma microbacia experimental em Cunha, São Paulo. Revista Árvore, Viçosa, v. 27, n. 2, p. 257-262, mar./abr. 2003.

BERTONI, J. C.; TUCCI, C. E. M. Precipitação. In: TUCCI, C. E. M. (Org.). Hidrologia: ciência e aplicação. 2. ed. Porto Alegre: UFRGS, 2001. p. 177-242. CALUX, J.;THOMAZ, E. L. Interceptação e precipitação interna: comparação entre floresta ombrófila mista e Pinus elliotttii var. elliotti. Revista Eletrônica do Curso de Geografia, Jataí, n. 19, p. 24-39, 2012.

FERREIRA, S. J. F.; LUIZÃO, F. J.; DALLAROSA, R. L. G. Precipitação interna e interceptação da chuva em floresta de terra firme submetida à extração seletiva de madeira na Amazônia Central. Acta Amazônica, Manaus, v. 35, n. 1, p. 55-62, 2005.

KELLMAN, M.; ROULET, N. Stemflow and throughfall in a tropical dry forest. Earth Surface Processes and Landforms, Sussex, v. 15, p. 55-61, 1990.

KLASSEN, W.; LANKREIJER, H. J. M.; VEEN, A. W. L. Rainfall interception near a forest edge. Journal of Hydrology, Amsterdam, n. 185, p. 349-361, 1996.

LIMA, W. P. Interceptação da chuva por povoamentos de eucaliptos e de pinheiros. IPEF, Piracicaba, n. 13, p. 75-90, 1976.

MONTE, M. A.; REIS, M.G. F.; REIS, G. G.; LEITE, H. G.; CACAU, F. V.; ALVES, F. F. Crescimento de um clone de eucalipto submetido a desrama e desbaste. Revista Árvore, Viçosa, v.33, n.5, p. 777-787, 2007.

MOURA, A. E. S. S.; CORREA, M. M.; SILVA, E. R.; FERREIRA, R. L. C.; FIGUEIREDO, A. C.; POSSAS, J. M. C. Interceptação das chuvas em um fragmento de floresta da Mata Atlântica na bacia do Prata, Recife, PE. Revista Árvore, Viçosa, v. 33, n. 3, p. 461-469, 2009.

NEAL, C.; ROBSON, A.; HALL, R. L.; RYLAND, G.; CONWAY, T.; NEAL, M. Hydrological impacts of hardwood plantation in lowland Britain: preliminary findings on interception at a forest edge, Black Wood, Hampshire, Southern England. Journal of Hydrology, Amsterdam, v. 127, n. 1/4, p. 349-365, 1991.

OLIVEIRA, L.; COSTA, R. F.; SOUSA, F. A. S.; COSTA, A. C. L.; BRAGA, A. P. Precipitação efetiva e interceptação em Caxiuanã, na Amazônia Oriental. Acta Amazonica, Manaus, v. 38, n. 4, p. 723-732, 2008. 
OLIVEIRA JUNIOR, J. C.; DIAS, H. C. T. Precipitação efetiva em fragmento secundário da Mata Atlântica. Revista Árvore, Viçosa, v. 29, n. 1, p. 6-15, jan./fev. 2005.

RADAMBRASIL. Projeto Radambrasil: levantamento de recursos naturais. Rio de Janeiro: DNPM, 1984.

REGALADO, L. B. Composição e distribuição de aves passeriformes em uma parcela de mata do Morro de Araçoiaba (Floresta Nacional de Ipanema, Iperó/SP) utilizando um sistema de informação geográfica. 1999. 118 p. Dissertação (Mestrado em Engenharia Ambiental) - Escola de Engenharia de São Carlos, São Carlos, 1999.

RODRIGUES, V. A. Redistribuição das chuvas pelas copas de um povoamento de seringueira, José Bonifácio, SP. Revista do Instituto Florestal, São Paulo, v. 21, n. 1, p. 19-26, jun. 2009.

SCHEER, M. B. Fluxo de nutrientes pela precipitação pluviométrica em dois trechos de floresta ombrófila densa em Guaraqueçaba, Paraná. Revista Floresta, Curitiba, v. 39, n. 1, p. 117-130, 2009.

SOUZA, P.; MARTOS, H. L. Estudo do uso público e análise ambiental das trilhas em uma unidade de conservação de uso sustentável: floresta Nacional de Ipanema, Iperó, SP. Revista Árvore, Viçosa, v. 32, n. 1 p. 91-100, fev. 2008.

THOMAZ, E. L. Avaliação de interceptação e precipitação interna em capoeira e floresta secundária em Guarapuava, PR. Geografia, São Paulo, v. 14, n. 1, p.47-60, jan./jun. 2005.

Received: June 09, 2011; accepted: September 19, 2013. 
